\title{
Levels of N7-(2-hydroxyethyl)guanine as a molecular dosimeter of drug delivery to human brain tumors ${ }^{1}$
}

\author{
William J. Bodell, ${ }^{2}$ Donald D. Giannini, Samuel Hassenbusch, and Victor A. Levin \\ Brain Tumor Research Center of the Department of Neurological Surgery, University of California, \\ San Francisco, CA 94143-0555 (W.J.B., D.D.G.); Department of Neurosurgery (S.H.) and Department of \\ Neuro-Oncology (V.A.L.), The University of Texas M.D. Anderson Cancer Center, Houston, TX 77030
}

The level of N7-(2-hydroxyethyl)guanine (N7-HOEtG), one of the DNA alkylation products formed by 1,3-bis(2chloroethyl)-1-nitrosourea (BCNU) treatment, was measured in human brain tumor samples by high performance liquid chromatography with electrochemical detection. The tumors from 6 recurrent chemotherapy-naïve patients with recurrent glioblastoma multiforme were analyzed as controls. The mean level of N7-HOEtG in DNA of these specimens was $0.42 \mathrm{pmol} / \mathrm{mg}$ DNA. Samples were also obtained from a patient with a recurrent glioblastoma multiforme after direct intratumoral therapy with BCNU in ethanol (DTI-015). The levels of N7HOEtG in the samples distal, medial, and adjacent to the site of injection were $0.8,2.6$, and $369.5 \mathrm{pmol} / \mathrm{mg}$ DNA, respectively. Comparison of the level of N7-HOEtG detected in the distal sample after injection with BCNU in ethanol with the mean level of the untreated samples indicated that it was not sufficiently different to be ruled out as a chance occurrence. Comparison of the levels of N7HOEtG in the medial and adjacent brain tumor samples with the mean level of the control samples showed values

Received 17 January 2001, accepted 6 April 2001.

${ }^{1}$ Supported by National Institutes of Health Grant CA80685.

${ }^{2}$ Address correspondence and reprint requests to William J. Bodell, University of California, Box-0555, San Francisco, CA 94143-0555.

\footnotetext{
${ }^{3}$ Abbreviations used are as follows: BCNU, 1,3-bis(2-chloroethyl)-1nitrosourea; CENU, chloroethylnitrosourea; DTI-015, BCNU in ethanol; GBM, glioblastoma multiforme; HPLC-EC, high performance liquid chromatography with electrochemical detection; N7-HOEtG, N7-(2hydroxyethyl)guanine.
}

that were approximately 6 - and 879 -fold higher. These results demonstrate that intratumoral administration of BCNU in ethanol produces significant levels of DNA alkylation and suggest that DNA adduct measurements provide a unique molecular dosimeter to evaluate delivery of alkylating agents to brain tumors. Neuro-Oncology 3 , 241-245, 2001 (Posted to Neuro-Oncology [serial online], Doc. 01-003, June 20, 2001. URL <neuro-oncology.mc.duke.edu>)

$\mathrm{P}$ atients with $\mathrm{GBM}^{3},{ }^{3}$ the most common primary brain tumor, have a life expectancy of approximately 1 year. Treatment of these tumors involves surgery, radiation therapy, and chemotherapy. The first drug approved by the FDA for treatment of these tumors, BCNU, is still widely used (Mahaley, 1991). CENUs such as BCNU are bifunctional alkylating agents that crosslink DNA leading to their cytotoxicity against dividing tumor cells (Dolan and Pegg, 1997). Unfortunately, BCNU treatment is generally palliative rather than curative because of tumor cell resistance.

The observed resistance of intracranial brain tumors to long-term therapeutic response is most likely a combination of their unique physical properties and the biology of glial malignancies. Glial tumor cells can infiltrate deep into the surrounding brain and be encompassed by a typical intact blood-tumor barrier that reduces or prevents drug uptake (Levin et al., 1980). In terms of their biologic properties, gliomas have a low mitotic index (Lamborn et al., 1999); at least 50\% of them show mutations or alterations in cell-signaling pathways, such as $p 53$ (Kleihues and Cavenee, 1997); the tumors are invasive (Kleihues and Cavenee, 1997); they are resistant to the induction of apoptosis (Nagane et al., 1996); they show 
a 10 -fold variation in cytotoxic response to treatment with nitrosoureas (Bodell et al., 1988); and levels of $\mathrm{O}^{6}$ alkylguanine DNA alkyltransferase play a determinant role in their therapeutic response to nitrosoureas (Belanich et al., 1996; Jaeckle et al., 1998).

To address these properties, new strategies have been developed for increasing the effectiveness of BCNU for treatment of GBM tumors. These strategies include combinations of BCNU with other agents, such as procarbazine (Levin and Prados, 1992), temozolamide (Schold et al., 2000), and $\mathrm{O}^{6}$-benzylguanine (Friedman et al., 1998), to inhibit $\mathrm{O}^{6}$-alkylguanine DNA alkyltransferase. Another approach to improve therapy has been to modify drug delivery. This approach has included intracarotid administration of BCNU (Rogers et al., 1991) and intratumoral administration of BCNU (Brem et al., 1995). Recently, a solvent-mediated drug delivery system for the intratumoral treatment of human brain tumors with BCNU has been developed (Pietronigro et al., 1999). The potential importance of these new therapeutic approaches for brain tumor therapy is obvious. However, the use of clinical end points to evaluate their effectiveness can require up to several years.

Upon administration, BCNU undergoes hydrolytic decomposition to form both chloroethylating and hydroxyethylating species (Ludlum, 1990). These intermediates react with nucleophiles within the cell to form at least 13 DNA adducts. One of the principal DNA adducts produced by treatment with BCNU is N7HOEtG. (Bodell, 1999). The level of DNA adducts produced by treatment with BCNU and other CENUs is linearly related to the treatment concentration (Bodell, 1990; Ye and Bodell, 1997). This suggests that the measurement of DNA adduct levels in glioma samples after treatment with BCNU may provide a molecular dosimeter for delivery of CENUs to brain tumors.

Electrochemical detection has been demonstrated to be a very sensitive method for the quantification of DNA adducts. We have developed and optimized electrochemical detection in conjunction with HPLC resolution for the quantitative analysis of N7-HOEtG (Ye and Bodell, 1997). We propose that application of this procedure may allow us to quantify DNA adduct levels in gliomas after treatment with BCNU.

The purpose of this study was to determine whether we could use HPLC-EC to quantify the level of N7HOEtG formed in a human brain tumor after intratumoral administration of DTI-015.

\section{Materials and Methods}

\section{Patient Sample}

Patient G.H. had a recurrent GBM and signed a consent form, approved by the Investigational Review Board of the University of Texas M. D. Anderson Cancer Center, for intratumoral treatment with DTI-015 and for tumor sampling. G.H. was treated by stereotactic intratumoral injection with $4 \mathrm{ml}$ DTI-015 at a DTI-015 concentration of 60 $\mathrm{mg} \mathrm{BCNU} / \mathrm{ml}$ ethanol. Sixty minutes after injection, stereotactic biopsies were taken from the tumor at dis- tances of $0.9 \mathrm{~cm}$ (adjacent), $2.4 \mathrm{~cm}$ (medial), and $3.9 \mathrm{~cm}$ (distal) from the injection site. Subtotal surgical resection of tumor followed collection of biopsies. The samples were quick-frozen and stored at $-80^{\circ} \mathrm{C}$ until DNA isolation.

\section{Control Brain Tumor Samples}

Recurrent GBM tumor samples from patients who had not received prior chemotherapy were obtained from the University of California Department of Neurosurgery Tissue Bank.

\section{Isolation of DNA}

The DNA was isolated from individual tumor specimens using a modified chloroform-isoamylalcohol extraction. After initial isolation, the DNA was digested with a combination of pancreatic ribonuclease A and T2 ribonuclease, followed by proteinase $\mathrm{K}$. The DNA-containing solution was extracted with chloroform-isoamylalcohol (24:1). DNA was precipitated using sodium acetate and ethanol and collected by centrifugation, then dissolved in $0.1 \times$ saline-sodium citrate buffer. DNA concentration was determined from its absorbance at $260 \mathrm{~nm}$. The concentration was determined from the relationship that 1 absorbance unit is equivalent to a concentration of $50 \mu \mathrm{g}$ $\mathrm{DNA} / \mathrm{ml}$.

\section{Thermal Hydrolysis}

For quantification of N7-HOEtG, $100 \mu \mathrm{g}$ DNA in $100 \mu \mathrm{l}$ phosphate-buffered saline $(\mathrm{pH} 8)$ was heated at $100^{\circ} \mathrm{C}$ for $30 \mathrm{~min}$ (Ye and Bodell, 1997). The samples were chilled in a ice bath, and $100 \mu \mathrm{l}$ cold $1 \mathrm{M} \mathrm{HCl}$ was added. The samples were centrifuged at $1300 \times \mathrm{g}, 0^{\circ} \mathrm{C}$ for 10 min to collect the DNA. The pellet was washed once with $100 \mu \mathrm{l}$ cold $1 \mathrm{M} \mathrm{HCl}$ and centrifuged as described above. Both supernatants were combined and adjusted to $\mathrm{pH} 6$ with the addition of $4 \mathrm{M}$ sodium acetate $(\mathrm{pH}$ 6.4) and concentrated $\mathrm{NH}_{4} \mathrm{OH}$. The hydrolysates were filtered prior to prepurification.

\section{Prepurification of N7-HOEtG}

An HPLC-UV system consisting of a model 250 PerkinElmer (Cupertino, Calif.) solvent delivery system with a PerkinElmer LC 235 diode array detector was used. A 5- $\mu \mathrm{m} \mathrm{C-18} \mathrm{reversed} \mathrm{phase} \mathrm{analytical} \mathrm{column} \mathrm{with}$ column dimensions of $250 \times 4.6 \mathrm{~mm}$ (Econosphere; Alltech Associates, Deerfield, Ill.) was employed for the prepurification separations. Column temperature was set at $30^{\circ} \mathrm{C}$ with a PerkinElmer column oven. For prepurification of N7-HOEtG, the column was eluted with an isocratic mobile phase of $50-\mathrm{mM}$ sodium acetate, $\mathrm{pH} 5.4$, with $5 \%$ methanol. Fractions corresponding to the elution of N7-HOEtG were collected and reduced in volume. After standard solutions of either N7-HOEtG or DNA samples were injected onto the column, blank samples were injected, and fractions corresponding to the elution of N7-HOEtG were collected and subsequently analyzed by HPLC-EC. Under these conditions of analysis, no carryover of N7-HOEtG between samples was detected. 


\section{HPLC-EC Detection}

The HPLC-EC system consists of an ESA model 580 solvent delivery system with an SSI pulse dampener (Alltech Associates, Deerfield, Ill.) coupled to an ESA Coulochem II electrochemical detector with an ESA 5010 analytical cell (Chelmsford, Mass.). A 5- $\mu \mathrm{m}$ Econosphere column was employed for the analytical separations. Column temperature was set at $30^{\circ} \mathrm{C}$. For quantitation of N7HOEtG, the column was eluted with an isocratic mobile phase of $50-\mathrm{mM}$ sodium acetate $(\mathrm{pH} 5.1)$ with $10 \%$ methanol.

Electrode 1 was set at oxidation potential of +400 $\mathrm{mV}$; electrode 2 was set at oxidation potential of +825 $\mathrm{mV}$ for N7-HOEtG. Electrochemical response was digitized with a Nelson interface and analyzed using TurboChrom 4 software (PerkinElmer). Standard curve(s) was generated by measuring electrochemical response after injecting standard solutions of N7-HOEtG (Chemsyn Science Laboratories, Lenexa, Kan.) over the concentration range of 0.05 to 1.0 pmol. Levels of adducts in the individual samples were determined by comparison with the standard curve. Using DNA reacted with radiolabeled CENUs, we determined that the detection and recovery of N7-HOEtG by HPLC-EC was $\geq 80 \%$ (D.D. Giannini and W.J. Bodell, unpublished data, 2000; Ye and Bodell, 1997).

The coefficient of variation for intraassay and interassay measurements was between $2 \%$ and $10 \%$ and dependent on the level of N7-HOEtG in the sample.

\section{Statistical Analysis}

Statistical analysis was performed using Sigma Stat v 2.03 (SPSS Inc., Chicago, Ill.). The results are expressed as mean \pm SD.

\section{Results}

Initial studies were carried out to determine the level of N7-HOEtG in DNA isolated from recurrent GBM tumors with no prior chemotherapy. DNA was isolated from six such samples. N7-HOEtG levels in the samples were quantified by HPLC-EC (Table 1). In these samples, the N7-HOEtG levels ranged from not detectable to $0.94 \mathrm{pmol} / \mathrm{mg}$ of DNA. In samples where the N7HOEtG level was at or below the level of quantitation, we assigned to these samples a value of $\leq 0.25 \mathrm{pmol} / \mathrm{mg}$ DNA, which was the limit of quantitation. The mean N7-HOEtG level in the six untreated brain tumor samples was $0.42 \pm 0.27 \mathrm{pmol} / \mathrm{mg}$ DNA.

DNA was isolated from three brain tumor samples that were located distal $(3.9 \mathrm{~cm})$, medial $(2.4 \mathrm{~cm})$, and adjacent $(0.9 \mathrm{~cm})$ to the site of DTI-015 injection. As shown in Table 2, N7-HOEtG levels in the brain tumor samples after intratumoral DTI-015 injection were dependent on the distance from the site of injection. As may be expected, the highest N7-HOEtG level was found in the tumor sample adjacent to the site of injection. N7-HOEtG levels then decreased as the distance from the site of injection increased. Comparison of the mean N7-HOEtG level in
Table 1. N7-HOEtG levels in recurrent human brain tumors that had not received chemotherapy before surgery

Sample N7-HOEtG (pmol/mg DNA)

\begin{tabular}{lc}
\hline Control 1 (SF-3673) & 0.53 \\
Control 2 (SF-3311) & 0.94 \\
Control 3 (SF-3186) & 0.31 \\
Control 4 (SF-3225) & $\leq 0.25^{\mathrm{a}}$ \\
Control 5 (SF-3499) & $\leq 0.25^{\mathrm{a}}$ \\
Control 6 (SF-3507) & $\leq 0.25^{\mathrm{a}}$ \\
\hline
\end{tabular}

${ }^{a} \mathrm{~N} 7-\mathrm{HOEtG}$ levels in these samples were less than or equal to the limit of quantitation of the method, which was $0.25 \mathrm{pmol} / \mathrm{mg}$ DNA.

the untreated brain tumor samples with the N7-HOEtG levels measured in the brain tumor samples after DTI-015 administration showed levels that were approximately 2fold higher for the distal, 6-fold higher for the medial, and 879 -fold higher for the adjacent tumor sample.

If we assume that the N7-HOEtG levels in the untreated tumor samples were normally distributed, we can use this assumption to evaluate whether the N7HOEtG levels detected in the treated tumor samples occurred by chance. For this, we will assume that any level of N7-HOEtG that was 3 SDs or more outside the mean value of the untreated sample levels did not occur by chance. Using this argument, we would determine that the N7-HOEtG level detected in the distal sample was not sufficiently different from the mean level of the control samples to rule out this level being observed due to a chance observation. In contrast, the N7-HOEtG levels detected in the medial and adjacent tumor samples were not likely due to a chance observation.

\section{Discussion}

The level of N7-HOEtG has been measured in DNA isolated from nontreated, recurrent GBMs. In three of the samples, the N7-HOEtG level was at or below the level of quantitation that was $0.25 \mathrm{pmol} / \mathrm{mg}$ of DNA. For those samples, we assigned the value of $\leq 0.25 \mathrm{pmol} / \mathrm{mg}$ DNA and used these values to calculate a mean value for the control samples. The mean N7-HOEtG level in the control samples was determined to be $0.42 \mathrm{pmol} / \mathrm{mg}$ DNA or $\approx 0.6 \mathrm{pmol} / \mu \mathrm{mol}$ guanine. This N7-HOEtG level is similar to that reported in DNA isolated from control brains of mice $(0.3 \mathrm{pmol} / \mu \mathrm{mol}$ guanine $)$ and rats $(0.2 \mathrm{pmol} / \mu \mathrm{mol}$ guanine $)$ and from human lymphocytes (2.5 pmol//umol guanine) (Wu et al., 1999). The source of N7-HOEtG in untreated tissue samples has been proposed to be oxidation of endogenously produced ethylene to ethylene oxide (Filser et al., 1992; Wu et al., 1999).

Table 2. N7-HOEtG levels in human brain tumor samples after intratumoral treatment with DTI-015

\begin{tabular}{lc} 
Sample & N7-HOEtG $(\mathrm{pmol} / \mathrm{mg}$ DNA) \\
\hline Distal $(3.9 \mathrm{~cm})$ & 0.8 \\
Medial $(2.4 \mathrm{~cm})$ & 2.6 \\
Adjacent $(0.9 \mathrm{~cm})$ & 369.5 \\
\hline
\end{tabular}


DNA was isolated from samples of a recurrent GBM tumor treated by intratumoral injection of DTI-015 (240 $\mathrm{mg} \mathrm{BCNU}$ in $4 \mathrm{ml}$ ethanol). The level of N7-HOEtG detected in the distal tumor sample was not sufficiently different from the levels detected in the untreated tumor samples to rule out this observation due to chance. In contrast, the N7-HOEtG levels detected in the tumor samples medial and adjacent to the site of DTI-015 injection were approximately 6- and 879-fold higher, respectively, than the mean value for the untreated GBM tumors. This increase in the N7-HOEtG level is consistent with the interpretation that intratumoral administration of DTI015 produces very significant levels of DNA alkylation.

We have measured the level of N7-HOEtG produced by injection of a 9L intracerebral tumor with $1 \mathrm{mg} \mathrm{BCNU}$ in $15 \mu \mathrm{l} \mathrm{ETOH}$. The level of N7-HOEtG detected by HPLC-EC analysis of the DNA isolated from the 9L brain tumor sample was $6.2 \mathrm{pmol} / \mathrm{mg}$ DNA (D.D. Giannini and W.J. Bodell, unpublished data, 1999.). If we use the level of N7-HOEtG detected in the 9L rat brain tumor following intratumoral injection of $1 \mathrm{mg}$ of $\mathrm{BCNU}$ and multiply it by the equivalent dose of BCNU given to the patient $(240 \mathrm{mg})$, the resultant value is 1480 pmol N7$\mathrm{HOEtG} / \mathrm{mg}$ DNA. Comparison of the extrapolated value $(1480 \mathrm{pmol})$ with the actual level detected in the adjacent tumor sample (Table 2) shows that they are reasonably close given the nature of the extrapolation made.

As noted, numerous novel approaches are being developed for the delivery of therapeutic agents to brain tumors. The determination of whether these new approaches have had a significant impact on the delivery of the agent to the brain tumor is an important question in their evaluation. Because the antitumor activity of CENUs is dependent on DNA binding, the most useful pharmacokinetic parameter would be levels of DNA-bound drug. Using radiolabeled BCNU and CCNU, this approach can be applied in rodent tumor models (Levin et al., 1978); however, this is not possible in human tumors. The results of this study show that DNA adduct formation can be measured in brain tumor samples following administration of alkylating chemotherapeutic agents. This technique can be used to evaluate whether these new methods have increased the delivery of agents to brain tumors and the relationship between administered dose and effective levels of alkylating agents. In addition, this methodology will allow comparison of the levels of DNA adducts formed in tumors of patients with the levels of DNA adducts formed in intracerebral human tumor models treated with alkylating chemotherapeutic agents. These comparisons will provide a unique molecular pharmacologic link between the results observed in clinical studies with those observed in tumor model systems.

\section{Acknowledgments}

We thank Dolores Dougherty of the Department of Neurosurgery Tissue Bank at the University of California at San Francisco for providing the untreated brain tumor specimens and Mary Malec and Kathleen Lamborn of the Department of Neurosurgery for their assistance in sample selection and suggestions regarding data analysis. We also express our appreciation to Brian Ross of the University of Michigan for providing the $9 \mathrm{~L}$ tumor treated with BCNU.

\section{References}

Belanich, M., Pastor M., Randall, T., Guerra, D., Kibitel, J., Alas, L., Li, B., Citron, M., Wasserman, P., White, A., Eyre, H., Jaeckle, K., Schulman, S., Rector, D., Prados, M., Coons, S., Shapiro, W., and Yarosh, D. (1996) Retrospective study of the correlation between the DNA repair protein alkyltransferase and survival of brain tumor patients treated with carmustine. Cancer Res. 56, 783-788.

Bodell, W.J. (1990) Molecular dosimetry for sister chromatid exchange induction and cytotoxicity by monofunctional and bifunctional alkylating agents. Mutat. Res. 233, 203-210.

Bodell, W.J. (1999) Effect of cations on the formation of DNA alkylation products in DNA reacted with 1-(2-chloroethyl)-1-nitrosourea. Chem. Res. Toxicol. 12, 965-970.

Bodell, W.J., Tokuda, K., and Ludlum, D.B. (1988) Differences in DNA alkylation products formed in sensitive and resistant glioma cells treated with $\mathrm{N}$ (2-chloroethyl)-N-nitrosourea. Cancer Res. 48, 4489-4492.

Brem, H., Ewend, M.G., Piantadosi, S., Greenhoot, J., Burger, P.C., and Sisti, M. (1995) The safety of interstitial chemotherapy with BCNU-loaded polymer followed by radiation therapy in the treatment of newly diagnosed malignant gliomas: Phase I trial. J. Neurooncol. 26, 111-123.

Dolan, M.E., and Pegg, A.E. (1997) $0^{6}$-benzylguanine and its role in chemotherapy. Clin. Cancer Res. 3, 837-847.

Filser, J.G., Denk, B., Törnqvist, M., Kessler, W., and Ehrenberg, L. (1992) Pharmacokinetics of ethylene in man: Body burden with ethylene oxide and hydroxyethylation of hemoglobin due to endogenous and environ- mental ethylene. Arch. Toxicol. 66, 157-163.

Friedman, H.S., Kokkinakis, D.M., Pluda, J., Friedman, A.H., Cokgor, I., Haglund, M.M., Ashley, D.M., Rich, J., Dolan, M.E., Pegg, A.E., Moschel, R.C., McLendon, R.E., Kerby, T., Herndon, J.E., Bigner, D.D., and Schold, S.C., Jr. (1998) Phase I trial of $O^{6}$-benzylguanine for patients undergoing surgery for malignant glioma. J. Clin. Oncol. 16, 3570-3575.

Jaeckle, K.A., Eyre, H.J., Townsend, J.J., Schulman, S., Knudson, H.M., Belanich, M., Yarosh, D.B., Bearman, S.I., Giroux, D.J., and Schold, S.C., Jr. (1998) Correlation of tumor $\mathrm{O}^{6}$-methylguanine-DNA methyltransferase levels with survival of malignant astrocytoma patients treated with bis-chloroethylnitrosourea: A Southwest Oncology Group study. J. Clin. Oncol. 16, 3310-3315.

Kleihues, P., and Cavenee, W.K. (1997) Pathology and Genetics of Tumours of the Nervous System. Lyon, France: International Agency fo Research on Cancer. pp. 1-9.

Lamborn, K.R., Prados, M.D., Kaplan, S.B., and Davis, R.L. (1999) Final report on the University of California-San Francisco experience with bromodeoxyuridine labeling index as a prognostic factor for the survival of glioma patients. Cancer 85, 925-935.

Levin, V.A., and Prados, M.D. (1992) Treatment of recurrent gliomas and metastatic brain tumors with a polydrug protocol designed to combat nitrosourea resistance. J. Clin. Oncol. 10, 766-771.

Levin, V.A., Kabra, P.A., and Freeman-Dove, M.A. (1978) Relationship of 1,3bis(2-chloroethyl)-1-nitrosourea (BCNU) and 1-(2-chloroethyl)-3-cyclo- 
hexyl-1-nitrosourea (CCNU) pharmacokinetics of uptake, distribution, and tissue/plasma partitioning in rat organs and intracerebral tumors. Cancer Chemother. Pharmacol. 1, 233-242.

Levin, V.A, Patlak, C.S, and Landahl, H.D. (1980) Heuristic modeling of drug delivery to malignant brain tumors. J. Pharmacokinet. Biopharm. 8, 257296.

Ludlum, D.B. (1990) DNA alkylation by the haloethylnitrosoureas: Nature of modifications produced and their enzymatic repair or removal. Mutat. Res. 233, 117-126.

Mahaley, M.S., Jr. (1991) Neuro-oncolgy index and review (adult primary brain tumors): Radiotherapy, chemotherapy, immunotherapy, photodynamic therapy. J. Neurooncol. 11, 85-147.

Nagane, M., Coufal, F., Lin, H., Bogler, O., Cavenee, W.K., and Huang, H.-J.S. (1996) A common mutant epidermal growth factor receptor confers enhanced tumorigenicity on human glioblastoma cells by increasing proliferation and reducing apoptosis. Cancer Res. 56, 5079-5086.

Pietronigro, D., Drnovsky, F., Cravioto, H., and Ransohoff, J. (1999) Stereotactic intratumoral injection of DTI-015 in a rat intracranial T9 gliosarcoma model. Proc. Am. Assoc. Cancer Res. 40, 583. (Abstract)
Rogers, L.R., Purvis, J.B., Lederman, R.J., Rosenbloom, S.A., Tomsak, R.L., Estes, M.L., Magdinec, M., Medendorp, S.V., and Boyett, J.M. (1991) Alternating sequential intracarotid BCNU and cisplatin in recurrent malignant glioma. Cancer 68, 15-21.

Schold, S.C., J., Kuhn, J.G., Chang, S.M., Bosik, M.E., Robins, H.I., Mehta, M.P., Spence, A.M., Fulton, D., Fink, K.L., and Prados, M.D. (2000) A phase I trial of 1,3 bis(2-chloroethyl)-1-nitrosourea plus temozolomide: $A$ North American Brain Consortium study. Neuro-Oncology. [serial online], Doc. 99-26, December 9, 1999. URL http://neuro-oncology.mc.duke.edu Neuro-Oncol. 2, 34-39.

Wu, K.-Y., Scheller, N., Ranasinghe, A., Yen, T.-Y., Sangaiah, R., Giese, R., and Swenberg, J.A. (1999) A gas chromatography/electron capture/negative chemical ionization high-resolution mass spectrometry method for analysis of endogenous and exogenous N7-(2-hydroxyethyl)guaninein rodents and its potential for human biological monitoring. Chem. Res. Toxicol. 12, 722-729.

Ye, Q., and Bodell, W.J. (1997) Detection of N7-(2-hydroxyethyl)guanine adducts in DNA and $9 \mathrm{~L}$ cells treated with 1-(2-chloroethyl)-1-nitrosourea. J. Chromatogr. B. Biomed. Sci. Appl. 694, 65-70. 